\title{
Afdrif sjúklinga með óutskýrða kviðverki á bráðamóttöku
}

Ómar Sigurvin Gunnarsson ${ }^{1,2}$ kandídat

\section{Guðjón Birgisson² skurðlæknir \\ Margrét Oddsdóttiri, skurðlæknir † Lést 9. janúar 2009.}

Tómas

Guðbjartsson ${ }^{1,2}$ skurðlæknir

Lykilorð: kviðverkir, óútskýrðir kviðverkir, afdrif, rannsóknir, skurðaðgerð, bráðamóttaka.

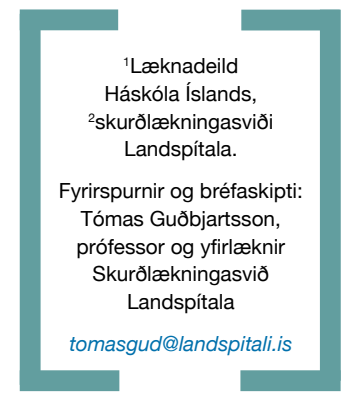

\section{Ágrip}

Tilgangur: Óútskýrðir kviðverkir er algengasta greining sjúklinga sem leita á bráðamóttöku vegna kviðverkja. Tilgangur pessarar afturskyggnu rannsóknar var að kanna afdrif pessara sjúklinga ári eftir útskrift af bráðamóttöku.

Efniviður og aðferðir: Rannsóknin náði til allra sjúklinga sem útskrifaðir voru með oútskýrða kviðverki af bráðamóttökum Landspítala í Fossvogi og við Hringbraut, 1. janúar til 31. desember 2005. Ekki voru teknir með sjúklingar á bráðamóttöku kvenna- eða barnadeildar. Skoðaðar voru sjúkraskrár sjúklinga sem leituðu aftur á bráðamóttöku vegna kviðverkja næstu 12 mánuði og skráð einkenni, staðsetning verkja, rannsóknaniðurstöður og útskriftargreining við endurkomu.

Niðurstöður: Alls leituðu 62.116 sjúklingar á bráðamóttökur Landspítala árið 2005 og voru $1411(2,3 \%)$ peirra útskrifaðir með greininguna oútskýrðir kviðverkir. Á næstu 12 mánuðum leituðu 112 (7,9\%) sjúklingar aftur á bráðmóttöku vegna kviðverkja, flestir tvisvar eða oftar. Við endurkomu fengu $27(24,1 \%)$ af 112 sértæka greiningu, en 85 voru útskrifaðir aftur með óútskýrða kviðverki. Gallsteinar greindust hjá 8 (29,6\%), botnlangabólga hjá 5 (18,5\%) og krabbamein hjá tveimur $(7,4 \%)$ sjúklingum. Skurðaðgerð var framkvæmd hjá 17 sjúklinganna (63\%) við endurkomu.

Ályktun: Tæp 8\% sjúklinga með óútskýrða kviðverki leituðu aftur á bráðamóttöku innan árs vegna kviðverkja. Um fjórðungur fékk sértæka greiningu við endurkomu sem leiddi til skurðaðgerðar í rúmlega helmingi tilfella, oftast vegna gallsteinavandamála eða botnlangabólgu. Niðurstöður benda til að bæta megi greiningu sjúklinga með kviðverki pegar peir koma fyrst á bráðamóttöku.

\section{Inngangur}

Kviðverkir eru algengt vandamál hjá peim sem leita læknis, en samkvæmt erlendum rannsóknum eru 4-5\% peirra sem koma á bráđamóttökur sjúkrahúsa par vegna kviðverkja. ${ }^{1,2}$ Eftir sögutöku, skoðun og rannsóknir er leitast við að finna orsökina og setja fram nákvæma greiningu. Sumir eru lagðir inn, til dæmis sjúklingar sem purfa aðgerð vegna botnlanga- eða gallblöðrubólgu. Aðrir eru sendir heim, oft með sértæka meðferð, til dæmis sýklalyf við pvagfærasýkingu eða ristilsarpabólgu. Orsök fyrir kvörtunum sjúklinga finnst pó ekki alltaf og eru peir pá útskrifaðir með greininguna óútskýrðir kviðverkir (non specific abdominal pain, NSAP).

Einkenni sjúklinga með óútskýrða kviðverki geta lagast af sjálfu sér. Í rannsókn Lukens og félaga voru til dæmis 59,1\% sjúklinga án einkenna premur vikum eftir útskrift, 28,6\% leið betur og aðeins 3,3\% leituðu aftur á bráðamóttöku innan mánaðar. ${ }^{3}$ Kviðverkir geta hins vegar tekið sig upp aftur, jafnvel löngu síðar. Í hollenskri rannsókn kvartaði til dæmis priðjungur sjúklinga um kviðverki ári eftir útskrift. ${ }^{4}$

Á síoustu áratugum hefur hlutfall sjúklinga með óútskýrða kviðverki farið lækkandi, aðallega vegna bættra greiningaraðferða. Í bandarískum rannsóknum fengu til dæmis 41,1\% kviðverkjasjúklinga greininguna árið 1972, borið saman við 24,9\% árið 1993. 1, 2, 5, 6 Á sama tíma fækkaði innlögnum sjúklinga með kviðverki úr 27,4\% i 18,3\%." ${ }^{1,2}$ Prátt fyrir framfarir í greiningartækni eru oútskýrðir kviðverkir enn algengasta greining sjúklinga sem leita á bráđamóttöku vegna kviðverkja. Greiningin er pví algengari en bæði botnlangabólga og gallsteinavandamál sem eru í öđru og priðja sæti. ${ }^{5,7}$ Hér á landi hefur vantað upplýsingar um afdrif pessa sjúklingahóps, ekki síst pegar litið er til lengri tíma. Markmið rannsóknarinnar var að rannsaka nánar afdrif sjúklinga sem útskrifaðir voru með óútskýrða kviðverki af bráðamóttökum Landspítala.

\section{Efniviður og aðferðir}

Rannsóknin var afturskyggn og náði til allra sjúklinga sem útskrifaðir voru með greininguna oútskýrðir kviðverkir af bráðamóttökum Landspítala í Fossvogi og við Hringbraut frá 1. janúar til 31. desember 2005. Komur á bráđamóttöku Kvennadeildar og Barnaspítala Hringsins voru ekki teknar með. Greiningar samkvæmt ICD-10 


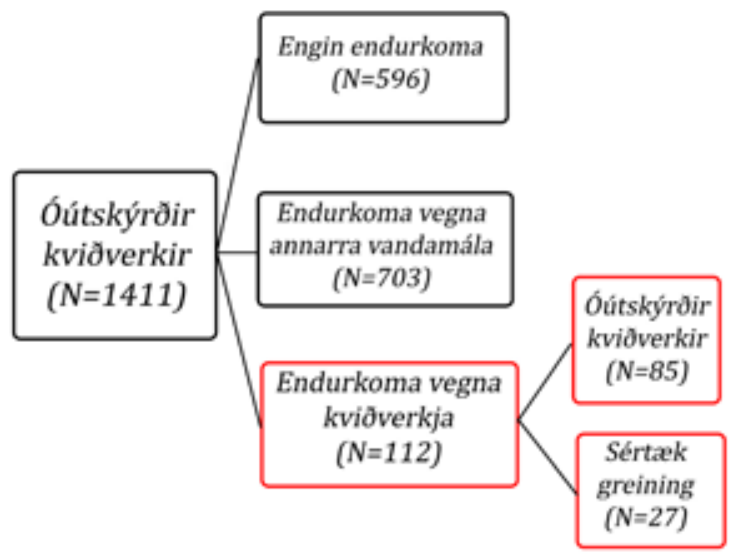

Mynd 1. Afdrif 1411 sjúklinga á fyrstu 12 mánuðunum eftir að peir voru útskrifaðir með óutskýrða kviðverki af bráðamóttökum Landspítala í Fossvogi og við Hringbraut á árinu 2005.

kerfinu sem töldust til óútskýrðra kviðverkja voru: Bráður kviðarholskvilli (R10.0), staðbundinn verkur í efri hluta kviðar (R10.1), grindarhols- og spangarverkur (R10.2), staðbundnir verkir annars staðar í neðri hluta kviðar (R10.3), annar og ótilgreindur kviðverkur (R10.4).

Sérstaklega var litið á sjúklinga sem leituðu aftur á bráðamóttöku vegna kviðverkja innan árs frá útskrift, eða frá 1. janúar 2006 til 31. desember 2006. Farið var í sjúkraskrár peirra og eftirfarandi upplýsingar færðar í gagnagrunn sem útbúinn var í forritinu FileMaker Pro 7.0: Aldur, kyn, komutími á bráðamóttöku, tegund komu (hvort sjúklingur kom sjálfur, með tilvísun frá lækni eða með

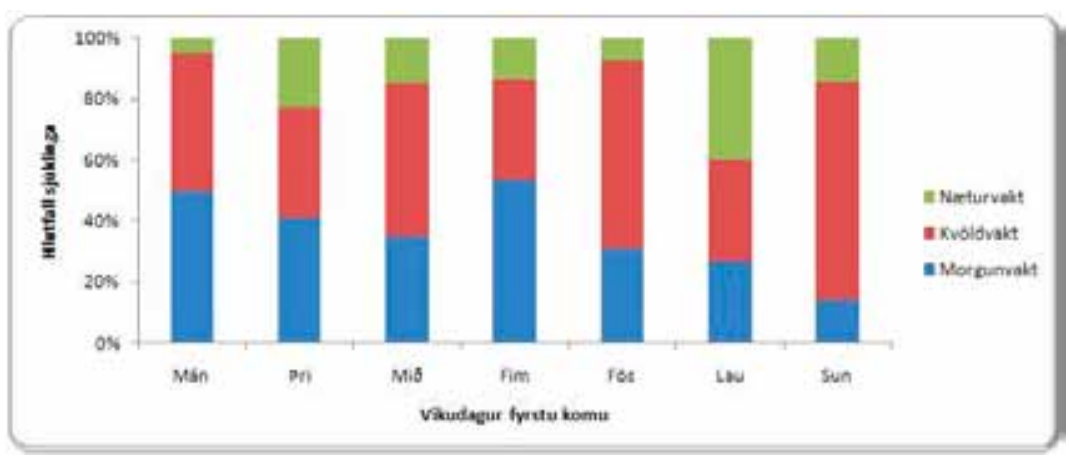

Mynd 2. Komudagur og -tími fyrstu komu 112 sjúklinga sem komu aftur á brádamóttöku vegna kviðverkja innan árs frá útskrift vegna óútskýrðra kviðverkja. Morgunvakt var skilgreind frá 8:00 til 16:00, kvöldvakt frá 16:00 til 24:00 og næturvakt frá mið̋ætti til 08:00. sjúkrabíl), tímalengd einkenna og önnur einkenni. Einnig voru skráð lífsmörk og staðsetning kviðverkja en kviðarholinu var skipt í níu svæði (mynd 3). Auk pess voru skráðar niðurstöður úr blóð-, pvag- og myndrannsóknum og hvort fengið hefði verið álit utanaðkomandi sérfræðings pegar sjúklingur lá upphaflega á bráðamóttöku. Loks var skráður legutími á bráðamóttöku og útskriftargreining við síðari komu/komur.

Sjúklingar sem leituðu aftur á bráðamóttöku vegna kviðverkja voru bornir saman við sjúklinga sem fengu greininguna óútskýrðir kviðverkir, en komu ekki aftur á bráđamóttöku vegna kviðverkja innan árs frá útskrift. Sjúklingar voru einnig bornir saman innbyrðis, pað er eftir pví hvort peir fengu sértæka greiningu við endurkomu eða ekki og afdrif peirra könnuð.

Útreikningar á meðaltölum, staðalfrávikum og marktækni voru gerðir í forritunum Excel og GraphPad Instat 3 (GraphPad Software, Inc.). Hópar voru bornir saman með tvíhliða t-prófi og Fisher's exact prófi. Tölfræðilegt marktæki miðast við p-gildi $<0,05$.

Áður en rannsóknin hófst fékkst leyfi frá lækningaforstjóra Landspítala, Siðanefnd Landspítala og Persónuvernd.

\section{Niðurstöður}

Árið 2005 komu 62.116 manns á bráđamóttökur Landspítala í Fossvogi og við Hringbraut. Af peim voru $1411(2,3 \%)$ útskrifaðir með greininguna oútskýrðir kviðverkir. Á bráðamóttöku við Hringbraut var hlutfallið 9,4\% af heildarkomum, 2,9\% á bráðavakt í Fossvogi og 0,1\% á gönguvakt í Fossvogi. Á mynd 1 eru sýnd afdrif pessara 1411 sjúklinga á fyrsta ári eftir útskrift. Alls leituðu 112 sjúklingar aftur á bráđamóttöku vegna kviðverkja og mynda peir rannsóknarhópinn. Hinir sjúklingarnir 1299 komu annaðhvort ekki aftur (n=596, 42,2\%) eða komu af öðrum ástæðum en vegna kviðverkja $(\mathrm{n}=703,49,8 \%)$.

Meðalaldur sjúklinganna 112 sem komu aftur

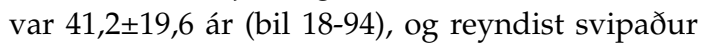
og hjá sjúklingunum 1299 sem ekki komu aftur, sem var 40,5 $\pm 19,2$ ár (bil 1-99) og er munurinn ekki marktækur ( $\mathrm{p}=0,76)$. Í hópi peirra 1299 sem ekki komu aftur voru $62,5 \%$ konur og $37,5 \%$ karlar. Af peim 112 sjúklingum sem komu aftur voru 77 konur $(68,8 \%)$ og 35 karlar $(31,2 \%)$ og var ekki marktækur munur á kynjahlutfalli pessara hópa $(p=0,22)$. Alls leituðu 57 sjúklingar af 112 oftar en tvisvar á bráðamóttöku vegna kviðverkja. Var meðaltal endurkoma 2,1 $\pm 1,7$ (bil 1-10) og komu sjúklingarnir allt frá nokkrum klukkutímum og upp í tíu mánuðum eftir útskrift. Á mynd 2 sést 
komudagur og -tími við fyrstu komu pessara 112 sjúklinga, og reyndist hann sambærilegur hjá hópnum sem ekki kom aftur innan árs. Flestar komur voru á priðjudegi, eða 19,6\%, en fækkaði pegar leið á vikuna og voru fæstar á sunnudögum, eða 6,3\%. Flestir sjúklingarnir komu á morgunvakt, eða 41,8\% alls hópsins. Af peim 112 sem komu í annað sinn, komu á flestir á kvöldvakt (44,6\%) en munurinn milli hópanna var ekki marktækur $(\mathrm{p}=0,62)$.

Við fyrstu komu á bráðamóttöku höfðu kviðverkir að meðaltali staðið yfir í um 4,5 sólarhringa, eða frá 15 mínútum og upp í 83 daga. Í 89,1\% tilfella höfðu verkirnir staðið í innan við viku. Flestir, eða 85 sjúklingar $(75,9 \%)$, komu á eigin vegum, 16 sjúklingar $(14,3 \%)$ voru fluttir með sjúkrabíl og 11 sjúklingar $(9,8 \%)$ komu eftir tilvísun læknis.

Á mynd 3 sést staðsetning kviðverkja við fyrstu komu sjúklinganna 112 sem komu oftar en einu sinni á bráðamóttöku, samkvæmt peim upplýsingum sem fram komu í sjúkraskrám. Upplýsingar vantaði hjá 15 sjúklingum (13,4\%). Flestir, eða 27 sjúklingar (24,1\%), lýstu dreifðum verkjum, 25 sjúklingar (22,3\%) höfðu verk í magál (epigastrium) og 17 sjúklingar (15,2\%) í hægri neðri fjórðungi. Kviðverkir annars staðar voru sjaldgæfari og enginn sjúklinganna kvartaði um verki umhverfis nafla eða í vinstri flanka. Af öðrum einkennum voru uppköst $(n=12)$, niðurgangur $(n=4)$ og ógleði $(n=2)$ algengust. Alls mældust sjö sjúklingar $(6,3 \%)$ með hita $\geq 38^{\circ} \mathrm{C}$ en líkamshiti var ekki skráður hjá 53 sjúklingum $(47,3 \%)$.

Blóðrannsóknir voru gerðar hjá 94 af pessum 112 sjúklingum, oftast á blóðhag, eða hjá 94 einstaklingum (83,9\%), CRP (c-reactive protein) hjá $85(75,9 \%)$ og amýlasi hjá 64 (57,1\%). Pvagrannsóknir voru gerðar í 64 tilfellum $(57,1 \%)$ og álit utanaðkomandi sérfræðings, oftast kvensjúkdómalæknis, fengið í 54 tilfellum (48,2\%). Myndrannsóknir voru gerðar í 63 tilfellum $(56,3 \%)$, oftast ómun, eða hjá 34 sjúklingum $(30,4 \%)$, kviðarholsyfirlit var gert hjá 30 sjúklingum (26,8\%) og 21 sjúklingur (18,8\%) fór í tölvusneiðmyndatöku. Loks fóru 12 sjúklingar í magaspeglun (10,7\%) og prír (2,7\%) í ristilspeglun.

Pegar könnuð voru afdrif sjúklinganna 112 kom í ljós að 27 peirra $(24,1 \%)$ höfðu fengið sértæka greiningu við endurkomu og 85 (75,9\%) fengu aftur greininguna óútskýrðir kviðverkir. Í töflu I eru hóparnir bornir saman við fyrstu komu. Meðalaldur hópanna var sambærilegur en karlar voru marktækt fleiri í hópi peirra sem fengu sértæka greiningu við síðari komu en peirra sem aftur voru greindir með óútskýrða

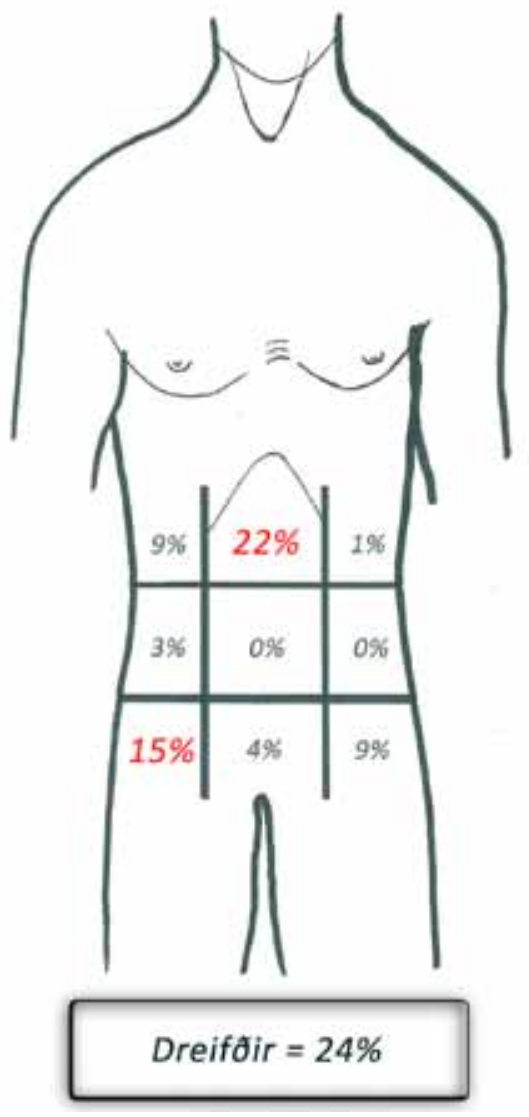

Mynd 3. Dreifing kviðverkja við fyrstu komu hjá 112 sjúklingum með óútskýrða kviðverki sem leituðu aftur á bráđamóttöku vegna kviðverkja innan árs frá ütskrift. Skiptingin í níu svæði miðast við lóðréttar línur frá miðju viðbeini beggja vegna og láréttar línur við neðri rif og mjaðmarnibbur. Alls höfðu $27(24,1 \%)$ sjúklingar dreifða kviðverki. Staðsetning var ekki tiltekin í sjúkraskrám 15 sjúklinga $(13,4 \%)$. Teikning: ÓSG kviðverki (48,1\% samanborið við 25,9\%; p=0,035). Hins vegar reyndist ekki marktækur munur á legutíma við fyrstu komu á bráðamóttöku, fjölda eða tegund rannsókna, eða hvort fengið var álit utanaðkomandi sérfræðings fyrir útskrift. Eftir skoðun og rannsóknir voru samtals 26 einstaklingar $(23,2 \%)$ hafðir inni til athugunar (observation) í meira en 12 klukkustundir, en hinir útskrifaðir heim án innlagnar. Sjúklingar sem fengu sértæka greiningu við endurkomu höfðu marktækt sjaldnar legið inni til athugunar við upphaflega komu á bráðamóttöku ( $\mathrm{p}=0,035)$.

Tafla I. Upplýsingar um fyrstu komu 112 sjúklinga sem leituðu aftur á bráđamóttöku vegna kviðverkja innan árs frá útskrift með óútskýrða kviðverki. Hópnum er skipt i tvennt; pá sem fengu aftur greininguna óútskýrðir kviðverkir við endurkomu $(n=85)$ og pá sem fengu sértæka greiningu ( $n=27)$. Gefinn er upp fjöldi og hlutfall (\%) i sviga, nema annað sé tekið fram.

\begin{tabular}{lccc}
\hline & $\begin{array}{c}\text { Oútskýrðir } \\
\text { kviðverkir }(n=85)\end{array}$ & $\begin{array}{c}\text { Sértæk greining } \\
(n=27)\end{array}$ & p-gildi \\
\hline Meðalaldur (ár, bil) & $41,5 \pm 20,9(11-94)$ & $40,1 \pm 15,3(18-74)$ & 0,75 \\
\hline Konur (\%) & $63(74,1)$ & $14(51,9)$ & 0,035 \\
\hline Meðallegutími (klst., bil) & $6,0 \pm 5,3(0,4-24,4)$ & $5,7 \pm 5,3(1,0-21,1)$ & 0,82 \\
\hline Innlögn til eftirlits í meira en 12 klst (\%) & $24(28,2)$ & $2(7,4)$ & 0,035 \\
\hline Fengið álit utanaðkomandi sérfræðings $(\%)^{*}$ & $45(52,9)$ & $9(33,3)$ & 0,08 \\
\hline
\end{tabular}

* oftast var um að ræða álit kvensjúkdómalæknis 
Tafla II. Afdrif 27 sjúklinga sem fengu sértæka greiningu á bráðamóttöku, innan við ári frá pví peir útskrifuðust með greininguna oútskýrðir kviðverkir. Einnig er sýndur tími frá upphaflegri komu á bráđamóttöku og par til sértæk greining fékkst, en slík greining fékkst ekki alltaf i fyrstu endurkomu. Loks eru sýnd afdrif sjúklinganna.

\begin{tabular}{|c|c|c|c|}
\hline Lokagreining & Fjöldi & Tími milli greininga & Meðferð \\
\hline Gallsteinar & 8 & 5 dagar - 9 mánuðir & gallblöðrutaka \\
\hline Botnlangabólga* & 5 & 10 dagar - 6 mánuðir & botnlangataka \\
\hline \multicolumn{4}{|l|}{ Krabbamein } \\
\hline Briskrabbamein $^{\star *}$ & 1 & 3 mánuðir & lyfjameðferð \\
\hline Nýrnakrabbamein & 1 & 7 mánuðir & nýrnabrottnám \\
\hline \multirow[t]{2}{*}{ Brisbólga } & 2 & 1 dagar & stuðningsmeðferð \\
\hline & & 5 vikur & stuðningsmeðferð \\
\hline \multirow[t]{2}{*}{ Magasár } & 2 & 4 dagar & lyfjameðferð \\
\hline & & 3 vikur & lyfjameðferð \\
\hline Garnaflækja & 1 & 3 vikur & samvaxtalosun \\
\hline Pungun & 1 & 2 vikur & fóstureyðing \\
\hline Crohns sjúkdómur í smágirni & 1 & 2 mánuðir & lyfjameðferð \\
\hline Grindarholsbólga konu (PID) ${ }^{\star \star \star}$ & 1 & 4 dagar & kviðsjáraðgerð \\
\hline Ósæđargúlpur & 1 & 4 mánuðir & eftirlit \\
\hline Hvekksbólga (prostatitis) & 1 & 1 dagur & sýklalyfjameðferð \\
\hline Lungnabólga & 1 & 3 vikur & sýklalyfjameðferð \\
\hline Sykursýki (ketoacidosis) & 1 & 30 dagar & lyfjameðferð \\
\hline
\end{tabular}

*Öll tilfelli staðfest með vefjagreiningu. **Lést sjö mánuðum eftir fyrstu komu. ***Pelvic inflammatory disease.

Í töflu II sjást afdrif peirra 27 sjúklinga sem fengu sértæka greiningu við síðari komu. Að meðaltali liðu 55 \pm 76 dagar (bil 0-271 dagar) frá útskrift uns sértæk greining fékkst, par af fengu $74 \%$ peirra greininguna innan mánaðar. Hjá fimm sjúklingum fékkst ekki sértæk greining fyrr en í annarri til fjórðu komu, par af voru tveir með gallsteina og tveir með botnlangabólgu. Allir pessir fimm sjúklingar fóru í skurðaðgerð, en alls fóru 17 af 27 sjúklingum (63\%) í skurðaðgerð við endurkomu. Hjá átta sjúklingum var hafin önnur meðferð en hjá tveimur var meðferð ekki breytt prátt fyrir nákvæmari greiningu. Á tímabilinu lést einn sjúklingur af 112, nánar tiltekið úr briskrabbameini, og dánarhlutfall pví 0,9\%.

\section{Umræða}

Pessi rannsókn sýnir að 2,3\% peirra rúmlega 62.000 sjúklinga sem leituðu á bráðamóttökur Landspítala fengu greininguna óútskýrðir kviðverkir. Petta er sambærilegt við aðrar rannsóknir par sem petta hlutfall er yfirleitt á bilinu 1-3,2\% sjúklinga sem leita á bráðamóttökur.2,3,8 Aðeins á Landspítala er um að ræða rúmlega 1400 sjúklinga með óútskýrða kviðverki árlega. Par við bætist að talsverður fjöldi pessara sjúklinga, eða í kringum 8\%, leitar aftur á spítalann innan 12 mánaða vegna sömu kvartana, margir oftar en einu sinni. Pví er ljóst að óútskýrðir kviðverkir eru töluvert heilbrigðisvandamál hér á landi.

Karlar fengu marktækt oftar sértæka greiningu við endurkomu. Í pví sambandi verður að hafa í huga að ekki voru teknar með komur á bráðamóttöku kvenna- eða barnadeildar, sem aftur hefur áhrif á kynja- og aldursdreifingu hópanna.

Óutskýrðir kviðverkir eru greining með lágt næmi og sértæki, sem fyrst og fremst er notuð pegar aðrar greiningar hafa verið útilokaðar.? Áður en sjúklingarnir eru sendir heim af bráðamóttöku er brýnt að ganga úr skugga um að ekki sé pörf á innlögn eða skurðaðgerð. 3, 5, 9 Erlendar rannsóknir hafa sýnt fram á gildi pess að hafa góða verkferla við uppvinnslu pessara sjúklinga. Er pá meðal annars stuðst við lista yfir mismunagreiningar og blóð- og myndrannsóknir pantaðar samkvæmt ákveðnu kerfi. Sýnt hefur verið að með verkferlum sem pessum má spara bæði tíma og fé, auk pess sem greining verður markvissari. ${ }^{8}$ Á Landspítala voru verkferlar teknir í notkun pegar árið 2004, en mikilvægt er að peir séu notaðir rétt og endurskoðaðir reglulega, bæði til að tryggja öryggi sjúklinga og rétta notkun greiningarrannsókna.

Sjúklingar í pessari rannsókn voru flestir rannsakaðir við fyrstu komu annaðhvort með blóð- eða myndrannsóknum, eða 83,9\% hópsins. Pó hafði tæpur priðjungur $(27,7 \%)$ sjúklinga eingöngu gengist undir blóðrannsókn og 14,3\% voru hvorki rannsakaðir með blóð- eða myndrannsóknum. Í öðrum rannsóknum hefur verið bent á hversu ófullkomnar blóðrannsóknir eru til að fá fram sértæka sjúkdómsgreiningu hjá sjúklingum með kviðverki og til að ákveða hvort hægt sé að útskrifa pá., ${ }^{10}$ Petta á til dæmis við um mælingar á CRP en einnig amýlasa ${ }^{11,12}$ sem voru mældir hjá $75,9 \%$ og $57,1 \%$ sjúklinga í okkar rannsókn. Alls gengust 56,1\% sjúklinga undir myndrannsóknir, oftast ómskoðun eða tölvusneiðmyndatöku. Fjöldi myndrannsókna er svipaður og í sambærilegri bandarískri rannsókn, enda pótt par hafi hlutfall tölvusneiðmynda verið hærra. ${ }^{13}$ Tölvusneiðmyndir eru öflugt greiningartæki fyrir sjúklinga með bráða kviðverki og telja sumir að nota ætti rannsóknina oftar hjá pessum hópi sjúklinga. ${ }^{14-16}$ Hefðbundið kviðarholsyfirlit er hins vegar talin mun síðri rannsókn og á aðallega við pegar grunur er um garnastíflu eða frítt loft og ef aðrar sérstakar ábendingar liggja fyrir. ${ }^{17}$

Marktækt færri sjúklingar sem höfðu verið til athugunar í 12 klukkustundir eða lengur við fyrstu komu, fengu sértæka greiningu við 
endurkomu. Í erlendum rannsóknum hefur verið sýnt fram á að fækka megi óparfa blóð- og myndrannsóknum með pví að fylgja sjúklingum eftir í allt að hálfan sólarhring og endurmeta einkenni og skoðun reglulega. ${ }^{8}$ Sömuleiðis hefur verið sýnt fram á að endurinnlögnum megi fækka með pví að beina sjúklingum á endurkomudeild eða stofu. ${ }^{18}$

Hjá peim 27 sjúklingum sem fengu sértæka greiningu voru botnlangabólga og gallsteinavandamál algengustu greiningarnar. Niðurstöður okkar eru svipaðar og í rannsókn frá sænsku háskólasjúkrahúsi par sem til rannsóknar voru 2851 sjúklingur með óútskýrða kviðverki. ${ }^{7}$ Athyglisvert er að meðferð breyttist hjá 25 (92,6\%) peirra 27 sjúklinga sem fengu sértæka greiningu við endurkomu. Rúmur helmingur peirra, eða $63 \%$, gengust undir bráða skurðaðgerð og hjá öðrum priðjungi sjúklinga var beitt annarri sértækri meðferð, oftast sýklalyfjum. Í aðeins tveimur tilfellum var haldið áfram með óbreytta meðferð prátt fyrir breytta greiningu.

Tveir einstaklingar $(1,8 \%)$ greindust með illkynja sjúkdóma, báðir með krabbamein í kviðarholi. Er petta svipuð tíðni og í erlendum rannsóknum. ${ }^{19,20}$ Í báðum tilfellum var um að ræða ólæknandi sjúkdóm hjá sjúklingum yfir fimmtugu sem voru með útbreidd meinvörp við greiningu. Annar sjúklinganna lést á rannsóknartímabilinu og pví er dánartíðni í okkar rannsóknarhópi (0,9\%) sem er í samræmi við rannsókn Adams og félaga frá 1986, par sem hún var 1,2\%. ${ }^{21}$

Styrkur pessarar rannsóknar er að hún nær til stórs hóps sjúklinga par sem könnuð voru afdrif peirra í heilt ár frá útskrift. Rannsóknin er afturskyggn sem verður að teljast veikileiki, enda aðeins hægt að byggja á upplýsingum úr sjúkraskrám en ekki framskyggnri skráningu. Petta á ekki síst við um upplýsingar um staðsetningu kviðverkja og lífsmörk sem fengnar voru úr sjúkraskrám en ekki framskyggnri skráningu. Tölvugögn eru misáreiðanleg, til dæmis um greiningarnúmer, tímasetningu greininga og fleira. Auk pess er pað veikleiki að aðeins voru kannaðar endurkomur á bráðamóttöku en ekki annars staðar, til dæmis til heilsugæslulækna eða á önnur sjúkrahús. Erfitt er að komast yfir slíkar upplýsingar og var pví ákveðið að miða eingöngu við endurkomu á bráðamóttöku, enda hefur slíkt verið gert í öðrum rannsóknum. ${ }^{2}$ Eins og áđur kom fram voru sjúklingar á bráđamóttöku kvenna- og barnadeildar ekki teknir með í rannsóknina, sem eykur vægi karla og eldri sjúklinga í rannsóknarhópnum.

Langflestir peirra sem leituðu aftur á bráðamóttöku leituðu pangað vegna annarra vandamála en kviðverkja, eða 92\% hópsins. Ekki var reynt að greina pau nánar í pessari rannsókn, enda ekki markmið rannsóknarinnar. Pegar langur tími líður frá fyrstu komu að lokagreiningu er eðlilegt að velta fyrir sér hvort um nýtt vandamál sé að ræða. Í pessari rannsókn höfðu flestir pessara sjúklinga komið endurtekið á bráðamóttöku vegna kviðverkja áður en lokagreining fékkst. Á rannsóknartímanum voru starfræktar tvær aðskildar bráđamóttökur á Landspítala. Ekki var skoðaður munur á milli peirra, enda rannsóknarhópurinn of lítill til pess. Í dag er búið að sameina pessar bráđamóttökur og efni í nýja rannsókn að kanna árangur greininga á nýrri bráðamóttöku.

Hluti sjúklinga $(7,9 \%)$ sem útskrifaðist með óútskýrða kviðverki af bráðamóttöku leitaði læknis aftur innan árs vegna kviðverkja. Við endurkomu fékk tæpur fjórðungur peirra sértæka greiningu og rúmlega helmingur gekk undir skurðaðgerð, oftast vegna gallsteina eða botnlangabólgu. Pessar niðurstöður gefa vísbendingu um að bæta megi greiningu sjúklinga með kviðverki pegar peir leita fyrst á bráđamóttöku. Pessi rannsókn svarar pó ekki með hvaða hætti er hægt að bæta greiningu pessa sjúklingahóps, enda parf til pess framskyggna rannsókn með skipulögðu eftirliti eftir útskrift.

\section{Pakkir}

Ingibjörg Richter, kerfisfræðingur á upplýsingatæknisviði Landspítala, fær pakkir fyrir aðstoð við leit að sjúklingum í tölvuskrám Landspítala og Ragnar F. Ólafsson fyrir hjálp við tölfræðilega úrvinnslu.

\section{Heimildir}

1. Kamin RA, Nowicki TA, Courtney DS, et al. Pearls and pitfalls in the emergency department evaluation of abdominal pain. Emerg Med Clin N Am 2003; 21 : 61-9.

2. Powers RD, Guertler AT. Abdominal Pain in the ED: Stability and Change Over 20 Years. Am J Emerg Med 1995; 13: 301-3.

3. Lukens TW, Emerman C, Effron D. The Natural History and Clinical Findings in Undifferentiated Abdominal Pain. Ann Emerg Med 1993; 22: 690-6.

4. Muris JWM, Starmans R, Fijten GH, et al. One-year prognosis of abdominal complaints in general practice: a prospective study of patients in whom no organic cause is found. Brit J Gen Pract 1996; 46: 715-9.

5. de Dombal FT. The OMGE Acute Abdominal Pain Survey. Progress report, 1986. Scand J Gastroentero 1988; 144: 35-42.

6. Muris JWM, Starmans R, Fijten GH, et al. Abdominal Pain in General Practice. Fam Pract 1993; 10: 387-90.

7. Laurell H, Hansson LE, Gunnarsson U. Diagnostic pitfalls and accuracy of diagnosis in acute abdominal pain. Scand J Gastroentero 2006; 41: 1126-31.

8. Graff LG, Robinson D. Abdominal Pain and Emergency Department Evaluation. Emerg Med Clin N Am 2001; 19: 123-36.

9. Sandhu GS, Redmond AD, Prescott MV. Non-specific abdominal pain: a safe diagnosis? J R Coll Surg Edinb 1995; 40: 109-11. 
10. Rothrock SG, Pagane J. Acute Appendicitis in Children: Emergency Department Diagnosis and Management. Ann Emerg Med 2000; 36: 39-51.

11. Salem TA, Molloy RG, O’Dwyer PJ. Prospective study on the role of $\mathrm{C}$-reactive protein (CRP) in patients with an acute abdomen. Ann R Coll Surg Engl 2007; 89: 233-7.

12. Sutton PA, Humes DJ, Purcell G, et al. The role of routine assays of serum amylase and lipase for the diagnosis of acute abdominal pain. Ann R Coll Surg Engl 2009; 91: 381-4.

13. Nagurney JT, Brown DFM, Chang YC, et al. Use of diagnostic testing in the emergency department for patients presenting with non-traumatic abdominal pain. J Emerg Med 2003;2 5: 363-71.

14. Ng CS, Watson CJ, Palmer CR, et al. Evaluation of early abdominopelvic computed tomography in patients with acute abdominal pain of unknown cause: prospective randomised study. BMJ 2002; 325: 1387.

15. Sala E, Beadsmoore C, Gibbons D, et al. Unexpected changes in clinical diagnosis: early abdomino-pelvic computed tomography compared with clinical evaluation. Abdom Imaging 2009; 34: 783-7.
16. Stromberg $C$, Johansson $G$, Adolfsson A. Acute abdominal pain: Diagnostic impact of immediate CT scanning. World J Surg 2007; 31: 2347-58

17. Smith JE, Hall EJ. The use of plain abdominal $x$ rays in the emergency department. Emerg Med J 2009; 26: 160-3.

18. Onur $\mathrm{O}$, Guneysel $\mathrm{O}$, Unluer EE, et al. "Outpatient followup" or "Active clinical observation" in patients with nonspecific abdominal pain in the Emergency Department. A randomized clinical trial. Minerva Chir 2008; 63: 9-15.

19. Laurell H, Hansson LE, Gunnarsson U. Why Do Surgeons Miss Malignancies in Patients with Acute Abdominal Pain? Anticancer Res 2006; 26: 3675-8.

20. Jess P, Bjerregaard B, Brynitz S, et al. Prognosis of Acute Nonspecific Abdominal Pain - A Prospective Study. Am J Surg 1982; 144: 338-40.

21. Adams ID, Chan M, Clifford PC, et al. Computer aided diagnosis of acute abdominal pain: a multicentre study. $\mathrm{Br}$ Med J (Clin Res Ed) 1986; 293: 800-4.

\section{One year follow-up of patients discharged from the emergency department with non-specific abdominal pai}

Objective: Non-specific abdominal pain (NSAP) is the most common diagnosis of patients presenting to emergency departments (ED) with abdominal pain. The aim of this retrospective study was to investigate how many NSAP patients were re-admitted within 1 year to the ED with abdominal pain.

Material and methods: Included were all patients discharged with NSAP from adult EDs of Landspítali University Hospital (gynecology and pediatric EDs excluded), from January 1, 2005 to December 31, 2005. Hospital records for patients re-admitted within 12 months with abdominal pain were reviewed. Symptoms, pain location, blood tests and imaging results were registered, also the subsequent discharge diagnosis at re-admission. Results: Out of 62.116 patients attending the EDs in 2005, 1411 (2.3\%) were diagnosed with NSAP. During
12 months, 112 of these 1411 patients $(7.9 \%)$ were re-admitted to the ED with abdominal pain, most of them $\geq 2$ times. Out of 112 patients, 27 (24.1\%) were discharged with a more specific diagnosis; cholelithiasis (29.6\%), appendicitis (18.5\%) and gastrointestinal cancer (7.4\%) being the most common diagnosis. The other 85 (76\%) patients were diagnosed with NSAP again. Surgery was performed in 17 of the 27 (63\%) cases and 8 received specific treatment, most often antibiotics.

Conclusion: Almost $8 \%$ of discharged NSAP patients were re-admitted within a year for abdominal pain. At re-admission, one of four patients received a more specific diagnosis, most often cholelithiasis or appendicitis. Our results suggest that the diagnosis of patients with NSAP, at the first visit to the ED, could be improved.

Gunnarsson OS, Birgisson G, Oddsdottir M, Gudbjartsson T.

One year follow-up of patients discharged from the emergency department with non-specific abdominal pain. Icel Med J 2011; 97: 231-236

Key words: Abdominal pain, non-specific abdominal pain, prognosis, operations, emergency department

Correspondence: Tómas Guðbjartsson, tomasgud@landspitali.is

Barst: 6. október 2010, - sampykkt til birtingar: 5. janúar 2011 Hagsmunatengsl: Engin 